\title{
COST ESTIMATE REDUCTION USING ANALOGUE BUILDING MATERIALS
}

\author{
Laura PLATACE ${ }^{1}$, Sandra GUSTA ${ }^{2}$ \\ ${ }^{1,2}$ Latvia University of Agriculture, Latvia \\ Corresponding author e-mail: lauraplatace@inbox.lv
}

\begin{abstract}
One of the most important parameters that is currently used in public and private procurement in building process is the lowest price. The legislation of Latvia permits that an estimate forming process does not include criterions of quality, durability, and the potential high cost of maintaining the building during the exploitation time. That allows the constructor to reduce the cost estimate by using cheaper construction product or technology and does not let to provide the highest possible quality and the basic principle of sustainable construction. One of possible construction cost reduction solutions is the replacement of building material with equal building material, at the same time assessing the quality and replacement impact on the direct costs of estimate. The tasks of the research are: (1) to do literature review on what is an estimate, what an estimate includes and the basis of estimate; (2) to analyse the existing construction estimate, to evaluate the used construction materials and to study technical characteristics of materials, to explore a specific construction junction; (3) to replace the selected construction materials with analogous, thus reducing the direct costs of estimate; (4) to evaluate the affect of the price of the construction material on quality; (5) to compare the obtained cost estimate with the current cost estimate; (6) to implement laboratory research and to compare technical characteristics of the construction materials and analogue materials in order to check if they are the performing parameters that are defined in the declaration of performance. After comparing of the obtained direct costs of construction and analysing the quality of construction materials it is possible to provide the most appropriate offer of the direct costs of estimate to satisfy the customer's interests.
\end{abstract}

Keywords: Construction products, costs, estimate, quality, technical characteristics.

\section{INTRODUCTION}

The calculation of construction costs is essential for any construction works, as well as for the control of project process. It contains the exact organizational information - materials, number of machines, required workforce that is necessary to complete the project (Del Pico, 2012).

Currently there are no regulations in Latvia for estimation of construction costs, that would specifically determine how to draw up the estimate and what must be included in the estimate. Also there are no regulations, which define how extensive the descriptions of construction should be. The only legal act for the estimation of building costs is the Latvian Building Code LBN 501-15 "Procedure for Determination of Construction Costs" (Cabinet of Ministers, 2015).

(C2016 Laura Platace, Sandra Gusta. This is an open access article licensed under the 
Each customer is interested in achieving the desired goal, but most importantly it is to do the work, consuming the least possible financial resources.

Low costs of building object is one of the factors that influences the quality of construction. The lowest price principle cannot be assessed as objective and it does not guarantee the quality of the building. During the evaluation of offers it would be more objective to take into account the price-quality ratio (Ozolinšs, 2014).

Unfortunately, the lowest price shows the cheapest result. This correlation is observed directly in the public sector, where the customer does not wish to overpay and sometimes is even forced to choose the lowest offer. As a result there are a number of problems during the construction or exploitation time. In the private sector with paying capacity the building result usually is much more qualitative (Vite, 2014).

Customer or customer consultant must evaluate the existing risks by choosing the offer with the lowest price and carefully examine each offer. Otherwise in the long term perspective the customer will have to pay for the same work twice. Sometimes the actual price cannot be determined. The customer chooses the lowest price offer, but it does not mean that the object is going to be built by the presented value of building costs. During the execution of work or by the time when the construction should be completed additional works may be announced, which sometimes can make up to $15 \%$ extra costs of the starting price (Šnore, 2014).

The author studied the literature on the issue and obtained information about international experience and most common cost and quality failures in projects (Barber et al., 2000; Lopez \& Love, 2012; Low \& Yeo, 1998; Newton \& Christian, 2006). Sources about the process of estimating and causes of changing construction costs have been used as well (Hendrickson, 2008; Sun \& Meng, 2009).

In the cost system of the construction industry the construction costs are viewed separately from maintenance costs. It is common practice that for realization of intentions the cheapest price offer is selected, despite possible unreasonably high maintenance costs. For example, due to using cheaper materials after construction commitment in exploitation or after the end of the warranty period, defects may arise, which require additional costs.

\section{QUALITY OF CONSTRUCTION MATERIALS}

An important factor, that describes the quality of construction products, is the $\mathrm{CE}$ marking, which guarantees to customer certain quality requirements. $\mathrm{CE}$ marking granting procedure and requirements are determined by the European Parliament and Council Regulation No. 305/2011.

The new regulations for the circulation of construction products in the European Union (EU) came into full force on 1 July 2013.

The Construction Products Regulation provides several activities which simplify the procedure of obtaining CE marking thus reducing administrative workload for enterprises, particularly for micro-enterprises. The possibility of obtaining CE marking for their products will be simplified if their construction products placed on the market cause no concerns regarding their safety. Particularly 
simplified activities are planned for the construction products which are individually designed or manufactured within non-industrial production process.

The Construction Products Regulation provides the particular meaning of CE marking, as well as precisely determines the duties of manufacturers, distributors and importers. Harmonised technical specifications determine testing or calculation methods which are the most suitable to assess and verify the conformity of performance of a construction product to the harmonised standard or European Technical Assessment (Ministry of Economics of the Republic of Latvia, 2015).

Construction material manufacturer's declaration of performance certifies that product complies with the EU Regulation No. 305/2011 (Grīnvalds, 2013).

\section{PRICE FORMATION}

It is not possible for two estimators to draw up two identical estimates of the same object. This is due to the experience and knowledge, as well as the differences of modelling the work description, choice of technique, coefficient of building material consumption and the related evaluation of auxiliary work (Liepinšs, 2015).

Advantageous conditions for exact estimate, which actually is not possible nowadays, should comprise (Tāme mūsdienu būvprojektam, 2007):

1) stable material prices;

2) insufficient amount of labour;

3) invariable prices of resources;

4) adequate amount of time;

5) moderate competition

Within the process of the project realization construction costs are determined twice before launching the construction work. Originally the budgetary estimate for a developed project is drawn up, when the estimator is working in the interests of the customer.

When building purchase is announced, set work positions and amount, are used in project so that the estimators of the construction companies could compile the estimate and obtain the planned contract price (Fig. 1).

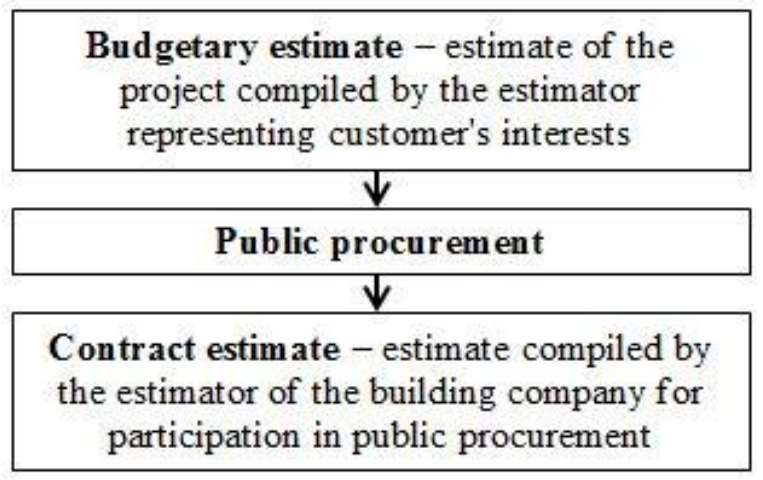

Fig. 1. Determination of building costs before the launching of the construction work. 
If the offer wins public procurement, fair construction costs cannot be determined, because the applicant wins with the lowest price offered, but it does not mean that the object really will be built by the specified amount. Very often when an applicant wins the procurement, additional works are launched during the construction works or shortly before the delivery of the object in operation, which sometimes is even $15 \%$ of the original costs (Šnore, 2014).

\section{METHODOLOGY OF RESEARCH}

The research is based on the real estimate of a family residential house which includes construction materials. During the research process certain building materials were selected, analysis of their technical data was done, analogue materials were found, their laboratorial and theoretical comparison was made, data were compiled and the costs of one unit of building material were compared. The alternatives for the selected building materials were searched - analogous building materials with the defined technical characteristics.

During the research analysis of technical properties, costs and comparison of analogue and similar construction materials were carried out. While carrying out the data collection of the research work, comparative method and analytical method was used.

As the residential house estimate is for an individual customer, rather than for public procurement, it is not expected that during the analysis the estimate could reveal dumping or abnormally low price existence.

The choice of the cheapest offer in itself excludes the possibility of the work to be performed qualitatively. Dumping not only brings losses to the economy in the form of unpaid taxes, but also degrades building industry as a whole. (Baltic News Network, 2010)

Comparable construction products were selected from the real estimate of the family residential home. The types of the researched construction materials are given in Table 1.

Table 1. Comparable Building Materials

\begin{tabular}{|c|l|l|}
\hline No. & \multicolumn{1}{|c|}{ Construction } & \multicolumn{1}{c|}{ Construction material } \\
\hline 1 & Partition walls & $\begin{array}{l}\text { Aerated concrete blocks: } \\
\text { Aeroc Classic, } 300 \mathrm{~mm}\end{array}$ \\
\hline 2 & $\begin{array}{l}\text { Partition wall construction, } \\
\text { ceiling cladding }\end{array}$ & Plasterboard Knauf GKB, $12 \mathrm{~mm}$ \\
\hline 3 & Roof insulation & $\begin{array}{l}\text { Rock wool: } \\
\text { Paroc ROS } 30,160 \mathrm{~mm} \\
\text { Paroc ROB } 80,20 \mathrm{~mm}\end{array}$ \\
\hline 4 & External wall insulation & $\begin{array}{l}\text { Rock wool: Rockwool Frontrock Max E, } \\
200 \mathrm{~mm}\end{array}$ \\
\hline
\end{tabular}


As an example, the author analyses one building material - aerated concrete blocks: Aerock Classic 300. Analogue building materials were researched following the main parameters: density, compressive strength, dimensions (Table 2).

Table 2. Analogue Products of Aerated Concrete Block and their Parameters

\begin{tabular}{|l|l|l|l|l|}
\hline & \multicolumn{1}{|c|}{$\begin{array}{c}\text { Aerock } \\
\text { Classic 300 }\end{array}$} & $\begin{array}{c}\text { RocLITE } \\
\text { UNIVERSAL } \\
\mathbf{3 0 0}\end{array}$ & $\begin{array}{c}\text { RocLITE } \\
\text { CLASSIC } \\
\mathbf{3 0 0}\end{array}$ & $\begin{array}{c}\text { Poritas PBDK } \\
\mathbf{3 0 0}\end{array}$ \\
\hline Density $\left(\mathrm{kg} / \mathrm{m}^{3}\right)$ & $425(+/-30)$ & $400-500$ & $400-500$ & $400(+/-50)$ \\
\hline $\begin{array}{l}\text { Compressive strength } \\
\left(\mathrm{N} / \mathrm{mm}^{2}\right)\end{array}$ & 3 & 3 & 3 & 2 \\
\hline Dimensions $(\mathrm{mm})$ & $300 \times 200 \times 600$ & $300 \times 200 \times 600$ & $300 \times 250 \times 600$ & $300 \times 200 \times 600$ \\
\hline
\end{tabular}

In Table 2 aerated concrete blocks - Poritas PBDK 300 are also included, as in the estimate it is not indicated if certain partition walls will be load bearing or nonload bearing walls. Thus the technical parameter - compressive strength - might not be the determining factor and would substantially reduce building costs of partition walls to 27.92 EUR per unit $\left(\mathrm{m}^{3}\right)$.

In Fig. 2 the listed prices of construction products are approximate and conform with average market prices in May 2016. The prices are taken from one supplier. Only one most appropriate analogue building material - RocLITE UNIVERSAL 300 , is selected for further analysis and the laboratory data test.

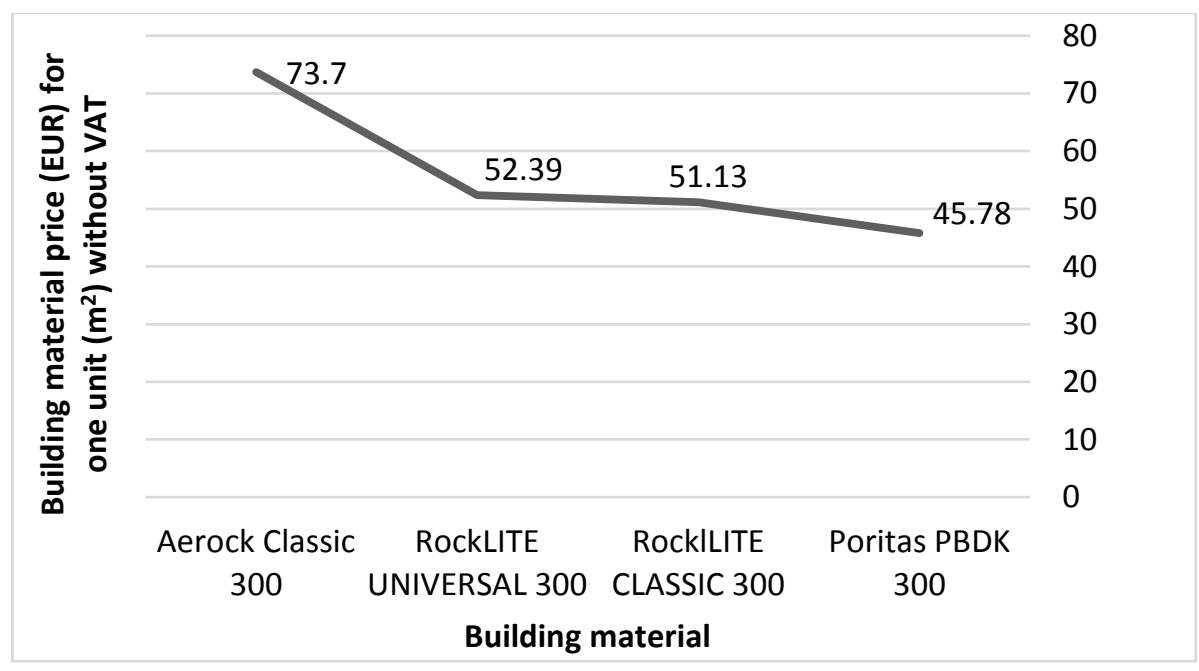

Fig. 2. Graphic comparison of aerated concrete block prices.

While in Latvia the lowest price is still the prevailing criterion in public procurement, in the United States of America there is literature available already since 1992 putting emphasis on the "life cycle" of construction products. 
The "life cycle" characterizes construction costs not only during the designing and construction, it also applies to the actual costs of building materials over a longer period of time. For instance, heat energy costs during operation are the costs of the "life cycle" of building. Choosing the cheapest offer of windows and the cheapest method of fitting during the construction could make economy in construction time, but savings would be lost, when windows would not comply with energy efficiency requirements (Bull, 1992).

When selecting similar construction products it was observed that unknown producers of building materials offer equivalent materials for remarkably lower prices.

It is also possible to purchase at lower price the construction products which visually conform with the necessary requirements but neither their manufacturer nor technical data are known, which allows the builder to act dishonestly and replace in the estimate the existing most expensive building material with cheaper one. Such situations can mostly happen in private building projects, which do not attract knowledgeable specialists to supervise the construction and defend the interests of the customer.

For laboratorial test and comparison two building materials of partition walls were selected. The first was Aeroc Classic 300 which is indicated in the analysed estimate, and the second analogue building material was RocLITE UNIVERSAL 300. These building products and laboratory test parameters are listed in Table 3.

Table 3. Comparable Building Materials and the Test Parameters

\begin{tabular}{|l|l|l|l|}
\hline No. & \multicolumn{1}{|c|}{$\begin{array}{c}\text { Building material } \\
\text { indicated in the estimate }\end{array}$} & \multicolumn{1}{|c|}{$\begin{array}{c}\text { Analogue building } \\
\text { material }\end{array}$} & Tested parameters \\
\hline 1 & $\begin{array}{l}\text { Aerated concrete blocks: } \\
\text { Aeroc Classic } 300\end{array}$ & $\begin{array}{l}\text { Aerated concrete blocks: } \\
\text { RocLITE UNIVERSAL } \\
300\end{array}$ & $\begin{array}{l}\text { Compressive strength } \\
\text { Thermal conductivity }\end{array}$ \\
\hline
\end{tabular}

Six samples were prepared for the compressive strength test - three samples of Aeroc Classic 300 and three samples of RocLITE UNIVERSAL 300, with dimensions $150 \times 150 \times 150 \mathrm{~mm}$ (Fig. 5).

The compressive strength test was done at the Faculty of Environmental and Civil Engineering of Latvia University of Agriculture with the help of hydraulic press ЗИМ П-125, which was designed for various construction product compressive strength testing (Fig. 3).

Six samples were prepared for thermal conductivity test - three samples of Aeroc Classic 300 and three samples of RocLITE UNIVERSAL 300, with dimensions $290 \times 290 \times 50 \mathrm{~mm}$ (Fig. 6) 


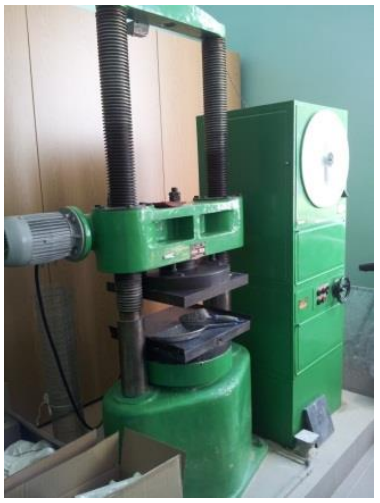

Fig. 3. Hydraulic press ЗИМ П-125.

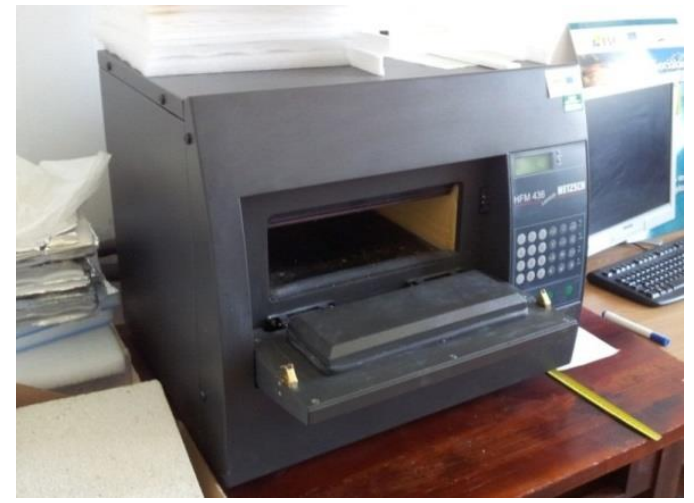

Fig. 4. Heat Flow Meter Netzsch HFM. 436/3/1 E Lambda.

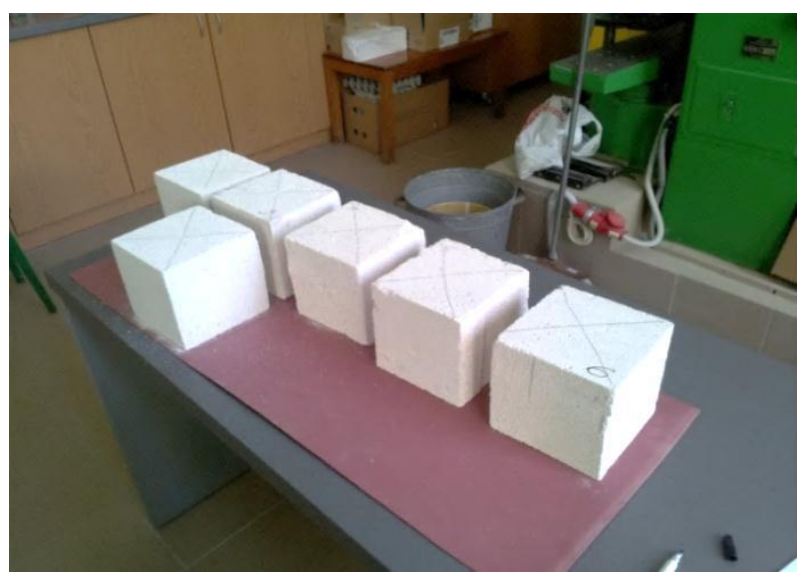

Fig. 5. Aerated concrete block samples for compressive strength test: Aeroc Classic 300 and RocLITE UNIVERSAL 300.

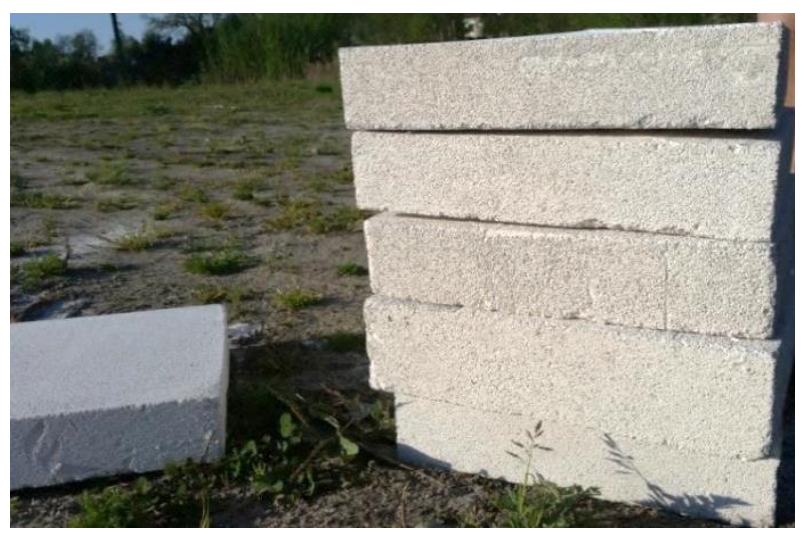

Fig. 6. Aerated concrete block samples for thermal conductivity test: Aeroc Classic 300 and RocLITE UNIVERSAL 300. 
Fig. 3 - Fig. 6 were taken by the author during the research.

The thermal conductivity test was done at the Laboratory of Physics Department of Latvia University of Agriculture, with the Heat Flow Meter Netzsch HFM 436/3/1 E Lambda (Fig. 4).

The sample of the construction material was placed in the measuring equipment (heat flow meter) and tested between two heat flux sensors with fixed temperature gradients (Netzsch, n.d.).

\section{FINDINGS AND RESULTS}

The compressive strength of samples of both construction materials: Aeroc Classic 300 and RocLITE UNIVERSAL 300, is close to the compressive strength declared by the producers $-3 \mathrm{~N} / \mathrm{mm}^{2}$, respectively $2.94 \pm 0.10 \mathrm{~N} / \mathrm{mm}^{2}$ and $2.99 \pm 0.04 \mathrm{~N} / \mathrm{mm}^{2}$. Scattering of results around average arithmetical, considering the number of taken measurements is not large $(5.8 \%$ and $2.3 \%)$. The value of mechanical properties of both analysed construction materials - compressive strength - conforms with the value declared by the manufacturer and both materials are analogues. The experimentally obtained values are close to the values indicated by manufacturers, which are as follows: Aeroc Classic $300>0.10 \mathrm{~W} /(\mathrm{m} \cdot \mathrm{K})$ and RocLITE UNIVERSAL 300 is $0.11 \mathrm{~W} /(\mathrm{m} \cdot \mathrm{K})$. Thermal conductivity coefficient values of both construction products are similar, and they are evaluated as analogues.

The research work laboratory measurements were gathered and the results were compared with the parameters defined by the producer of building materials. From the results it was found that the selected analogue materials are equivalent. As a result of the test, the cost estimate was revised and the change in the price was determined - if it either increased, remained the same or decreased. The laboratory research allowed to prove that certain cheaper materials are analogous. The research results reveal that it is possible to reduce direct construction costs.

\section{CONCLUSION}

The following conclusions were drawn:

1) The hypothesis of the research was confirmed - direct construction costs can be reduced by replacing the construction materials with analogous materials;

2) As prices of construction materials are variable it is necessary to carefully follow the changes. The cost of the same building material can differ with different building materials suppliers;

3) Selecting analogues construction materials showed that the unknown producers of construction materials offer equivalent materials for remarkably lower prices;

4) Customer or customer consultant needs to evaluate existing risks when choosing to implement the offer with the lowest price. When making the decision it is necessary to objectively evaluate the relation between the price and the quality. 


\section{REFERENCES}

Baltic News Network. (2010). Speciālists: cenu dempings būvniecībā sasniedzis kritisko līmeni [Price dumping in construction reached a critical level.]. Retrieved January 24, 2016, from http://bnn.lv/specialists-cenu-dempings-buvnieciba-sasniedzis-kritisko-limeni-2157

Barber, P., Sheath, D., Tomkins, C., Mark, H., \& Graves, A. (2000). The cost of quality failures in major civil engineering projects. Quality failure costs in civil engineering projects, 17(4/5), 479492. https://doi.org/10.1108/02656710010298544

Bull, J. W. (1992). Life Cycle Costing for Construction, Great Britain: Routledge.

Cabinet of Ministers. (2015). Latvijas būvnormatīvs LBN 501-15 "Būvizmaksu noteikšanas kārtība" [Latvian Building Code LBN 501-15 "Procedures for Determination of Construction Costs"]. Retrieved January 5, 2016, from http://likumi.lv/ta/id/274994-noteikumi-par-latvijas-buvnormativu-lbn-501-15-buvizmaksunoteiksanas-kartiba-

Del Pico, W. J. (2012). Estimating Building Costs for the Residential and Light Commercial Construction Professional ( $2^{\text {nd }}$ ed.). Hoboken, New Jersey: John Wiley \& Sons.

Grīnvalds, J. (2013). Kvalitātes izaicinājumi būvmateriālu ražotājiem [Quality challenge for building material producers.]. Retrieved January 15, 2016, from http://ptac.webmultishop.com/upload/7.razotaja_izaicinajumi.pdf

Hendrickson, C. (2008). Project Management for Construction. Pittsburgh, PA.

Liepiňš, G. (2015). Something about this and that, Latvia.

Lopez, R., \& Love, P. (2012). Design Error Costs in Construction Projects. Journal of construction engineering and management, 138, 585-593. https://doi.org/10.1061/(ASCE)CO.1943-7862.0000454

Low, S. P., \& Yeo, H. K. C. (1998). A construction quality costs quantifying system for the building industry. International Journal of Quality \& Reliability Management, 15(3), 329-349. https://doi.org/10.1108/02656719810198926

Ministry of Economics of the Republic of Latvia. (2015) Būvizstrādājumu aprites regulējums [Regulation of Circulation of Construction Products.]. Retrieved January 15, 2016, from https://www.em.gov.lv/lv/nozares_politika/buvnieciba/buvizstradajumu_aprites_regulejums/

Netzsch. (n.d.). Heat Flow Meter - HFM 436 Lambda [Brochure]. Retrieved May 14, 2016, from https://www.netzsch-thermal-analysis.com/en/products-solutions/thermal-diffusivityconductivity/hfm-436-lambda/

Newton, L., \& Christian, J. (2006). Impact of quality on building costs. Journal of Infrastructure Systems, 12(4), 199-206. https://doi.org/10.1061/(ASCE)1076-0342(2006)12:4(199)

Ozoliņš, A. (2014). Jāizslēe kļūdas iespējamības büvniecībā [The possibility of errors in construction.]. Retrieved April 30, 2016, from http://www.la.lv/jaizsledz-kludas-iespejamibabuvnieciba/

Sun, M., \& Meng, X. (2009). Taxonomy for change causes and effects in construction projects. International Journal of Quality \& Reliability Management, 27(6), 560-572. https://doi.org/10.1016/j.ijproman.2008.10.005

Šnore, I. (2014). Būvniecības prakse - zemāka cena konkursos kopsolī ar papildus darbiem [Construction Practice - lowest price in procurement pace with addition works.]. Retrieved January 24, 2016, from http://www.lsm.lv/lv/raksts/zinju-analiize/zinas/zemaka-cena-konkursos-kopsolii-ar-papildu-darbiem.a108284/

Tāme mūsdienu būvprojektam [Estimate for nowadays construction project]. (2007). Retrieved January 15, 2016, from http://www.abc.lv/article/tamesana/

Vite, D. (2014). “Zemālà cena būvniecībā: ekonomija vai dempings?” [Lowest price: economy or dumping?]. Retrieved January 5, 2016, from http://zurnalsiepirkumi.lv/zemaka-cena-buvniecibaekonomija-vai-dempings/ 


\section{AUTHORS' SHORT BIOGRAPHIES}

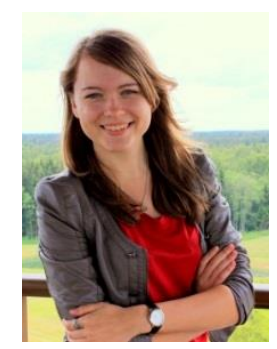

Laura Platace received the Bc. sc. ing. degree and the qualification of civil engineer from Latvia University of Agriculture in 2015. She received the Master degree in civil engineering from Latvia University of Agriculture in 2016.

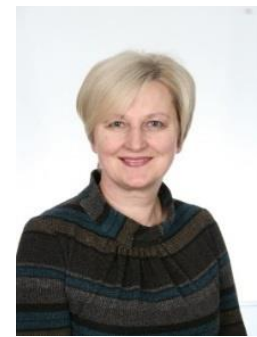

Sandra Gusta is an Associate Professor at the Faculty of Environmental and Civil Engineering, Head of the Department of Architecture and Building of Latvia University of Agriculture (LUA) Latvia. She obtained the Doctor's degree in economics from RTU and Master's degree in engineering sciences from LUA. She is the director of the $1^{\text {st }}$ level professional study program "Construction". Her professional qualification is engineer-economist, specialty - construction organization and management.

She is the author and co-author of more than 80 scientific publications. Her current research interests are sustainability development problems of construction, construction industry problems, including BIM.

She is a member of the Latvian Union of Civil Engineers and a board member of Board of the Latvian Economic Association. 